\title{
Aftershocks: Psychotechnics in the wake of apartheid
}

\author{
Ross Truscott and Michelle Smith \\ I watched the passing colors intently and noticed red passing a few \\ times [...] Then I reacted and was surprised when I heard that I had \\ been entrapped. ${ }^{1}$
}

\section{Introduction}

What we at first found intriguing about Simon Gush's Red, what the documentary and the installation seemed to mutually conjure, was the Mandela car as a body to be mourned. ${ }^{2}$ Mourning recurred as a latent theme through the documentary in the interviews with the workers at the Mercedes Benz factory - as Phillip Groom described Mandela's words on receiving the car, he stressed that its colour 'represented the many people that have spilled blood in this country to liberate it, to bring it to liberation', a notion the workers seemingly anticipated, as at the factory the Mandela car was, as Groom put it, 'literally carried', like a coffin, not simply a 'labour of love', but a work of mourning. 3 Attuned to this, the shell of Gush's reconstruction of the car body installed within the Goethe-Institut gallery in Johannesburg and then outside the Ann Bryant gallery in East London seemed to lie like a cadaver on an autopsy trolley (see image in the editor's introduction to this issue).

At the time of Red Assembly, which asked participants to consider the ways in which art pressures historical readings, it seemed to us that Red placed itself in relation to scholarship on mourning as a threshold condition of post-apartheid sociality. 4 The Mandela car seemed to present itself as an object of melancholic loss, not an encasing of an already lost object, but, as we argued in our paper at Red Assembly, which leaned on Giorgio Agamben's reading of melancholia, as an object shot through by 'the paradox of the intention to mourn that precedes and anticipates the loss of the object'. 5 The assemblage of the car, we thought, was an anticipatory act that conjured a post-apartheid social formation as lost so as to bring it into being, an act attended, we stressed, by rivalry; for while the workers interviewed in the documentary spoke of the euphoria of assembling the car, it was in fact only after its delivery that worker solidarity fragmented and things in the factory went awry. It was, then, we argued, in relation to this fragmentation that Gush's reproduction of the Mandela car, torn apart, should be understood as a questioning of the official reconciliatory narrative of the gift these workers offered. 
Like most of the participants at Red Assembly, we had not seen Red in a gallery, only encountered it online. The paper we presented thus dealt with images of Gush's installations from the screen, specifically an image of the bonnet of the car against the wall of the Goethe-Institut gallery. In the distorted reflection of this close up of the bonnet, we suggested, the gallery floor ran red with the blood that was spilled in the factory. ${ }^{6}$ In this bonnet, we saw the lines of the tiled gallery floor - and the ordered little rectangles they made, analogues, perhaps, for the social order of apartheid and its grids of intelligibility - bent by the curve of the metal. This 'speculative reproduction' of the car took that order, we thought, and offered a mirror image of a difference necessary to imagine a post-apartheid future, an image that the workers themselves had produced, through mourning ahead of time what had not yet been realized. Ultimately, though, the workers had failed, and in the mirror of the red bonnet we conjured nothing less than an echo of the problem of sexual difference upon which the male strikers had stumbled. To conclude this by now somewhat rapturous free association, Red recalled, we said, an impossible memory of the mother's body, the first hinge between the subject and the world.

While it seemed necessary at the time to think about sexual difference in relation to Red's scenes of masculinized homosociality, something about this formulation now feels forced, even false. But so did each subsequent attempt. Thinking about Red became, for us, something like being placed before a test apparatus that consisted of no more than a collection of vaguely meaningful, if richly overdetermined, objects that flashed up in front of us: it asked us to respond but entrapped us at each turn. If this is what Red became for us, though, it did so all of a sudden, later, after Red Assembly, after we had unknowingly taken this test many times, each new formulation a more fantastical response than the previous ones. This is not to foreclose on any interpretation of Red, for Red was, we maintain, the staging of a test that was not unprecedented; indeed, it was a test that recalled so many other tests that came to order life under apartheid. It was, in the Freudian sense, an uncanny (unheimlich) test, a test "which is secretly familiar, which has undergone repression and then returned from it'.7 Thus, rather than walk out of Red's test, we want to try to think about the relation between art and tests, and between this particular artwork and tests in the history that Red makes available as a repressed memory of apartheid to be seized.

\section{Verwoerd's experiment}

The role of tests in ordering the field of human potential in South Africa is of no small importance. Saul Dubow, for instance, has argued that intelligence testing can be seen as an essential part of the process that saw the hierarchical ranking of human society in terms of racial superiority'. 8 Apartheid was rationalized on the grounds of the unbridgeable differences between the races, an idea to which psychology lent the weight of its disciplinary reason and its arsenal of psychotechnical tests, specifically those assessing mental capacities. 
If Bantu administration 'gave apartheid its particular institutional form', 9 the labor bureau system, as Ivan Evans puts it, was the 'backbone of apartheid'. ${ }^{10}$ The Labor Bureau regulated the urban 'Bantu' population; its key objective was 'influx control', a balance between the need for 'Bantu' labor in the cities and the requirement that 'European' and 'Bantu' live separately. The Labor Bureau thus placed work-seekers in industries with labor shortages, kept the urban 'Bantu' population at a minimum, and restricted freefloating, unemployed 'Bantu'. Crucial to the labor bureau system was the vocational test conducted on work-seekers. But rather than a concern with matching workers with suitable employers, vocational tests simply gave the Labor Bureau the polished look of a scientific apparatus, upon which its authority rested. ${ }^{11}$ The test upon which the Labor Bureau effectively depended, however, was the pass law system: on the one hand, it was upon employment that a pass depended, and on the other, a pass law infringement meant that a 'Bantu' was rendered suitable to be deployed to farms with labor shortages. $^{12}$

The labor bureau system was formed in 1952 under Hendrik Frensch Verwoerd, then Minister of Native Affairs, soon to be Prime Minister. But vocational testing had interested Verwoerd for some time before that. After completing his doctorate in psychology, Die Afstomping van Gemoedsaandoeninge (the blunting of the emotions) at Stellenbosch University in 1924, Verwoerd spent time in Leipzig and Berlin. Besides vocational testing, his other interests lay in applied psychology, experimental technique, child psychology and Völkerpsychologie. ${ }^{13}$ On his return from Germany, via the US, he became Professor of Applied Psychology and Psychotechnics at Stellenbosch University. Given the stress laid on the 'psychological influences' in the operation of the apartheid state, ${ }^{14}$ it repays the effort to briefly review two experiments Verwoerd conducted during his early academic career.

In 'The distribution of "attention" and its testing', published in 1928 after his return from Germany, Verwoerd wrote of an experiment he conducted wherein he utilized an instrument constructed by the Organizations-Institut in Leipzig; an 'apparatus', Verwoerd notes, 'which is not only found in the psychological laboratories of German universities but is in everyday use for testing the distribution of attention in vocational guidance institutes, among others in the Landesberufsamt, Berlin, and the Berufsberatungsstelle, Leipzig. ${ }^{15}$ This apparatus had been developed to measure the 'distribution of attention', as the title of his article makes plain. Verwoerd's aim was to assess if it worked as it claimed to. Explaining his procedure, Verwoerd notes that test subjects ('Os') were asked to respond as quickly as possible to a set of prompts 'at the rate of 100 per minute' over a period of half an hour. ${ }^{16}$ This procedure was supplemented by an 'introspective report' by test subjects, and by 'observations on the O's method of performance'. ${ }^{17}$ Verwoerd's argument is that the test measures, not the 'distribution of attention, though test conditions can be manipulated so that it does, but, rather, what he calls the 
'distribution of marginal consciousness and automatic acting'. ${ }^{18}$ In measuring the distribution of attention', one of the challenges of the experiment is the prevention of 'rhythmical reaction', Verwoerd notes; to test 'attention' and the ability of an ' $O$ ' to sustain it over an extended period, the strips must 'alternate irregularly', for while such 'rhythmical movements' might be a measure of 'the distribution of marginal consciousness and automatic acting', it is not a measure of the 'distribution of attention', strictly speaking. ${ }^{19}$

In an article Verwoerd published in 1926, 'A Method for the Experimental Production of Emotions', he writes of an experiment designed to orchestrate various scenarios wherein emotions can be produced under experimental conditions and, thereby, studied, noting the effects of 'blunting' on the emotion produced. ${ }^{20}$ Conducted in Afrikaans before he went to Germany, though already under the influence of the Leipzig school, in this experiment Verwoerd uses a 'Ranschburg memory-apparatus', with two reaction paddles, one for the experimenter the other for the test subject. Test subjects were shown color disks and given a task to perform, their success or failure on the task, determined by the experimenter, producing different emotional states. After explaining the intricacies of the testing environment, Verwoerd notes how he applied punishment 'by means of shocks from a small inductorium' to aid the production of emotional states. ${ }^{21}$ In one variation of the shock experiment, 'Os' were told that they were to shock the 'E' for their own mistakes, the 'inductorium' handed over to the experimental subject in an exchange of roles meant to produce sympathy and shame in 'Os'. But this reversal is, in effect, a false one, always subordinate to the experiment's aim of producing, with rigorous regularity, a particular emotion and being able to anticipate its dissipation.

Subjects in these experiments were given strict roles ('Os' and 'Es'), and these positions were separated from each other, as Verwoerd states, 'by means of a partition', with 'the apparatus [...] placed as far as possible on Es side'. ${ }^{22}$ It is, thus, tempting to read these experiments as having taken place in the laboratories of apartheid, statements on its methodology that reveal the outlines of its divisions. However, the alarming aspect of Verwoerd's experiments is not that he trapped and shocked his research subjects, for these were students of psychology, colleagues, even, perhaps, himself. If apartheid is prefigured here, its lines must be discerned in the division between the experimental space and that space beyond which no experimentation was thought possible, in the division between experimental psychology and Völkerpsychologie. If within the experimental space there are 'partitions', then encircling this hierarchical space are frontiers, which, rather than including and differentiating, form the lines along which there occurs a total exclusion from the human. Experimental influx control, so to speak, occurred at the spatial threshold of the gates of the laboratory itself, for these were tests of what were considered to be normal adults capable of introspection. Indeed, Verwoerd places 
much store in introspection as a method, which, apart from placing his experiments historically within psychology's disciplinary formation in its break from philosophy, declares what sort of subject can be included in this community of possible human experts, some of whom were shocked.

Verwoerd's experiments have of course captured academic 'attention', so to speak, but the claim that the kernels of apartheid might be found in the psychological laboratory or in Verwoerd's interest in Völkerpsychologie is vehemently refuted on two points. First, that apartheid was not rationalized on the grounds of the Völkerpsychologie Verwoerd may have gleaned while in Germany. And second, that Verwoerd rejected outright racial differences in intelligence as measured by psychotechnical tests. Moreover, such tests, however much Verwoerd was interested in them, had already been critiqued in the 1920s, and by the 1940 S Simon Bisheuvel, founder of the National Institute for Personnel Research, effectively provided the critique of mental testing that would, if not eliminate such tests as instruments of racial oppression, then at least discredit this kind of application. ${ }^{23}$ Apartheid cannot be reduced to a single diagram of power, much less to a couple of experiments conducted in the early academic career of apartheid's architect. However, what arguments against a possible relation between apartheid and the discipline of psychology elide is that what has remained effective, and has left a lasting impression, was not the racist content of psychotechnical tests, which had been cleansed of their most racist assumptions and, therefore, applications, but the armature of the psychotechnical test itself. Empirically correct as they are, such refutations forestall an encounter with apartheid as a kind of technological apparatus.

For Verwoerd, in his 1926 experiment, the 'Ranschburg memory-apparatus' functions, despite its name, as a forgetting-machine, designed to activate working memory but suspend all else except the task at hand, intensified by the anticipation of inevitable shock. For Verwoerd, there is an immediacy to the reception of shock, a direct emotional effect that can be read off the instant reaction of an experimental subject. The only delay is that of 'blunting', which follows the initial production of an emotion; around this emotional reaction, a callous of consciousness, hardened to shock, forms. According to the conventions of early twentieth century experimental psychology - a rigorous thoughtlessness that persists in the discipline - the only concern is under what conditions this response can be reliably reproduced. It is possible, however, that the shocks of Verwoerd's experiments would only arrive decades later, once he left his academic post at Stellenbosch to take up a career in politics. Indeed, if we take Verwoerd seriously when he states that his test items 'show fundamental similarity to situations of every-day life', 24 that they are simplified versions of those found in the workplace and, one might say, in the shocks of 'every-day life', then we can understand the predicaments of the post-apartheid as a series of aftershocks both yet to cease and yet to arrive, lived in anticipation. 


\section{The art of testing}

The thinker who has, to our minds, theorized the relation between art and tests most provocatively is the German cultural critic, Walter Benjamin. Benjamin was interested in vocational tests from the early 1930s. On December 29 1930, Benjamin offered a radio broadcast, 'Carousel of Jobs', in the context of high unemployment, with low prospects of following one's heart, and many youths satisfied with 'snatching a spot where the risk of slipping back down - the danger of being driven out of the production process - seems as low as possible'. 25 Benjamin raises, right from the start of this broadcast, 'the great system of tests and manifold methods of evaluation' that had recently formed a 'new science, the science of work'. What Benjamin is interested in - and he dwells on examples from German Occupational Studies, then recently published in Leipzig, and on conversations with Hellmuth Bogen, Director of the Berlin Office for Professional Aptitude Tests - is the 'transformative power' of particular jobs. ${ }^{26}$ 'How does the job impact the individual, and through what? This is the question to which I would not only like to call your attention today, but for which I would also like to ask for your assistance'. 27 Thus, Benjamin asks his listeners to describe how their job has affected them, their moods, their attitudes, their relationships and, most of all, how the job has changed them. In short, Benjamin asks his listeners to observe themselves and their colleagues and to describe the effects they have felt and the transformations they have undergone.

Benjamin is speaking here about the same forms of testing, indeed the tests developed in the same institutions, that Verwoerd engages in his vocational test experiment. More startling are their common concerns. Indeed, Benjamin can be read as an unwitting critic of Verwoerd's experiment and, perhaps, of apartheid as it took shape as an unending series of unpassable tests. The test would reappear in Benjamin's now canonical 'Artwork' essay, wherein he places the vocational test at the heart of the filmic apparatus; the suggestion being that 'the performance of the actor is subjected to a series of optical tests' 28 that recall 'vocational aptitude tests'. ${ }^{29}$ The actor, Benjamin states, performs 'before a group of specialists - executive producer, director, cinematographer, sound recordist, lighting designer, and so on - who are in a position to intervene at any time'.$^{30}$ It is this intervention that is characteristic of 'all test performances', specifically those 'conducted openly, in agencies for testing professional aptitude'. ${ }^{1}$ While there is a panel of experts, the director assumes particular authority as he 'occupies exactly the same position as the examiner in an aptitude test'. ${ }^{32}$

The test an actor performs before an 'examiner' is one the spectator instantly recognizes, Benjamin suggests. If vocational tests had rendered 'the masses' as objects of 'specialist' observation, which had been used to place them into menial jobs, reducing them to machine-parts, the constellation of spectator- camera-actor in the cinematic apparatus invites an identification with a figure who has passed this vocational test, an inhabitation 
of a different world through a kind of phantasmatic 'triumph'. As Benjamin writes in the second version of the artwork essay:

Interest in this performance is widespread. For the majority of city dwellers, throughout the workday in offices and factories, have to relinquish their humanity in the face of an apparatus. In the evening these same masses fill the cinemas, to witness the film actor taking revenge on their behalf not only by asserting his humanity (or what appears to them as such) against the apparatus, but by placing that apparatus in the service of his triumph. 33

In the third version of the essay, Benjamin changes tack, arguing that identification with the actor on the screen is 'really an identification with the camera' and, therefore, that the 'audience takes the position of the camera'. 34 The spectator is thus placed in the position of an examiner of tests rather than that of a successful test subject, a successful job applicant. Without collapsing the difference between the second and third versions of the essay, in both texts 'the masses', for which such tests have come to organize their daily grind, appropriate the vocational test. Like the radiobroadcast, in which Benjamin asks his listeners to seize hold of the apparatus of the vocational test, film allows for, but does not guarantee, a refunctioning of the vocational test that lies both within and behind the apparatus of the film, and in everyday life.

Benjamin's thoughts about tests need to be put into the broader context of his work. In 'Some motifs on Baudelaire', Benjamin considers the 'fruitfulness' of Freud's Beyond the Pleasure Principle 'in situations far removed from those which Freud had in mind'. 35 In this essay, the function of consciousness is 'protection against stimuli' 36 While Freud is concerned with war neuroses, shell shock, Benjamin sees shock as a more or less permanent and widespread state. 37 Consciousness, for Benjamin reading Freud, is a 'protective shield' against the shocks of modern life; while shock is repressed by consciousness or rather, in Benjamin's terms, impressed, alienating the subject from their senses and full experience (Erfahrung). ${ }^{38}$ Film, in this context, becomes a kind of 'protective shield', or, in Susan Buck-Morss's words, a form of 'anaesthesia'.39 If the factory 'paralyses the imagination of the worker', its aim being 'to numb the organism, to deaden the senses, to repress memory', then film participates in this numbing. It, however, also holds out another possibility, which resides precisely in filmic shock. That is to say, film can claim no distance from modern shock, though it can make it useful.

On film and modern shock, Benjamin offers the following enigmatic formulation: 'In a film, perception in the form of shocks was established as a formal principle. That which determines the rhythm of production on a conveyor belt is the basis of the 
rhythm of reception in the film' ${ }^{40}$ The experience of film and its disjunctive rhythm recalls the experience of the worker on the conveyer belt: film repeats industrial shock, it numbs, just as work is mind-numbing, it induces amnesia and is received in a state of distraction. At at the same time, film also holds out another, often unrealized, potential: the cinema is a technical apparatus and a social space through which repressed memory can return and be made useful to the audience. It is in large part in relation to this potential that Benjamin developed his notion of 'unconscious optics [das Optisch-Unbewusste]'. ${ }^{41}$ Just as Freud had, Benjamin notes, 'isolated and made analyzable things which had heretofore floated along unnoticed in the broad stream of perception', so the camera 'brought about a similar deepening of apperception'.42 Resonant with what Freud called Nachträglichkeit, the afterwardness with which the repressed returns, symptomatically, like a photographic negative processed, Benjamin's concept of the 'optical unconscious' entails a temporality of delay through which that which has left an impression, marked the subject, will return suddenly, involuntarily, a reactivation of memory inscribed in the temporal structure of shock. 43

Here we can note another point at which Benjamin and Verwoerd cross paths. If, for Benjamin, consciousness is a 'protective shield' against shock, in the logic of Verwoerd's 1926 experiment, consciousness intervenes, blunts the emotion shock produces. The major difference between Verwoerd and Benjamin lies in their conceptions of the temporality of the shock. While Benjamin's formulation of shock's delayed arrival - and the messianic currents that pervade his work - cannot be collapsed into a psychoanalytic view, his understanding of film does lean on Freud's conception of repression and symptom formation. If, for Freud, a repressed wish, always sexual in content, encounters a limit (societal norms and psychic resistance to breaching them), then a symptom stands as the synthesis of these two antithetical forces - a compromise, a stand in, that offers gratification for that which never happened, could not happen. 44 For Benjamin, cinema is, in the Freudian sense, a symptom. If 'the desire of contemporary masses to bring things 'closer' spatially and humanly' encounters a limit (in the ritual and cult practices surrounding art, in the exclusions of auratic perception of painting and the privileges that accrue with it), then cinema is the compromise between 'the urge', as Benjamin puts it, 'to get hold of an object at very close range', that grasp offered, like a symptom, 'by way of its likeness, its reproduction'. And yet, as Benjamin insists, this does not render 'the masses' as symptoms, but analysts. 45

\section{An uncanny test}

Benjamin's treatment of film as a symptom of shock allows us to discern a test lodged in Red. The documentary begins with Thembalethu Fikizolo giving an account of the strike at the Mercedes Benz factory in 1990, an account that culminates in him missing, by three minutes, the deadline to return to work, at which point, he states, management dismissed him without a 
hearing. The question of time and timing, then, is foregrounded in the documentary from the first scene that lasts ten minutes. After this scene, the film cuts to shorter, roughly thirty-second snippets of other interviews with plant employees. The timing of the cuts that follow, however, remain within the same rhythm as the cuts of the first scene. While the interviews may have been conducted in slow ambling conversations, the film presents shots timed with the regularity of test items being responded to, each item reaching its limit at a minute, though most are completed more quickly, in double-time. ${ }^{46}$ Benjamin's formulation of 'the rhythm of production' and its relation to 'the rhythm of reception in the film' might be restated here as follows: the rhythm of reception at work in the documentary recalls the rhythm of a vocational test. The vocational test, properly speaking, is only a dramatization of 'the countless mechanized tests' set for workers. 47 As Benjamin notes, these kinds of vocational tests, like arriving on time at the gates of the factory, 'are performed unawares, and those who fail are excluded from the work process', 48 as Fikizolo was.

As this first scene is presented, the office in which Fikizolo sits may well have been the venue for a vocational test, though he is here on the opposite side of the table, the roles exchanged. The other workers interviewed are similarly framed, alone or in small groups, giving their observations of the events that unfolded at the Mercedes Benz factory, fulfilling Benjamin's radio broadcast wish, and perhaps Gush's and Cairns' too, that workers observe themselves, assume the role of experts. Of course, this was Verwoerd's wish, too, the wager of the documentary a repetition of Verwoerdian introspection. Perhaps the most poignant observation on the 'transformative power' of work is Phillip Groom's description of the main effect of working in the Mercedes Benz factory at the time of the strike: 'When you come to work, we used to say you leave your brains by the gate'. The shots to which the camera cuts during interviews are always from outside of the gates of the factory, precisely where the workers had abandoned their thought. In this way, while these still-like images to which the camera cut induced a state of distraction, they also, at the same time, framed these accounts as thoughtful. On the screen of Red, then, are 'actors' playing themselves and 'taking revenge', as Benjamin puts it, 'against the apparatus'; actors, with which the viewer is invited to identify, describing the faultless assemblage of Mandela's car in record time, without supervision, passing a vocational test with flying colors. 49 But through identification with the camera, the spectator becomes, also, an examiner of these examinations of the events, the spectator as an examiner face to face with other examiners, separated by the 'partition' of the screen. If the film comes across as flat in certain respects, it is precisely in this horizontality that its political claim is staged.

In Red as it was installed at the Ann Bryant, the theme of time and timing reappeared, perhaps by chance. In the second room of the gallery, the door panels of the car were suspended on the wall (figure 1). 
If this was a test item - the panels different shades of red, perhaps one of them a trap, as Verwoerd set traps with similar colored discs - the clock against the wall kept time. 50

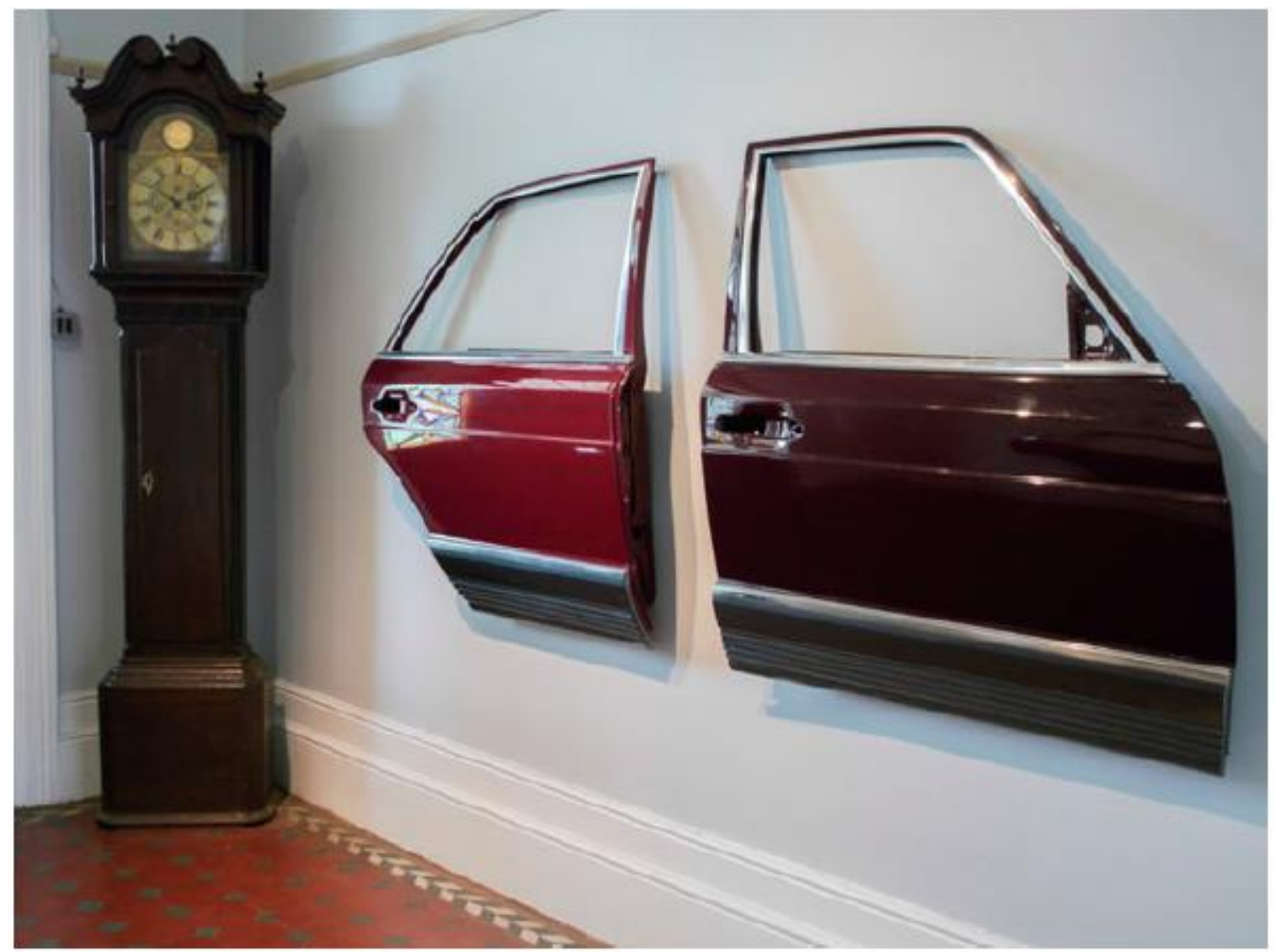

Figure 1. Simon Gush, Red, 2014. Installation view, Ann Bryant Gallery (detail). Courtesy the artist and Stevenson Gallery, Johannesburg and Cape Town. Simon Gush.

If art galleries have always been to some degree tests of proper modes of 'civilized' looking, the viewer who is observed here has the added pressure of being timed, of being watched, as it were, by the clock which stands on the threshold of these two rooms. The crucial difference, however, between Red and Verwoerd's tests, is that Red exhibited the test for all to see. Displays of vocational tests are not insignificant, for these kinds of tests and their traps are usually concealed - they are 'incapable of being publically exhibited to the degree one would desire', as Benjamin notes. ${ }^{51}$ Red's exhibited test still affected the viewer, entrapped, shocked, interpellated, though the frame of the gallery inserted a critical distance from the test, offered a location from which to apprehend the conditions of the test, to respond to the 'watchman' in the corner. 52 
In light of our reading of Verwoerd's experiments, the questions that haunt us after the shocks of Red's test do not concern who the reverberations of Verwoerd's experiment electrify and who not. Put differently, we are cautious of collapsing the difference between oppression and repression, between the excluded and the unthinkable. Though issues surrounding Red's politics of inclusion are certainly there to be interrogated, our questions concern Red's mediation of a memory of tests. How did Red's spatiality recall Verwoerd's psychotechnical experiments? How did the partitions and frontiers that organized Verwoerd's experiments reappear in Red, repeated but also reworked? ision between the ethnological field and the experimental space ision between the ethnological field and the experimental space become the documentary and the installation, factory and gallery? Is Red to Verwoerd's experiment what certain forms of early cinema were to the shocks of industrial modernity for Benjamin? And can the assemblage of the Mandela car be grasped as an attempt by the workers to seize hold of the apparatus of the test, to reverse the roles, to exert some control over the product of their labour? Did the exchange of roles - workers not only passing but examining - end up being a part of the game, in which the workers were not only to assemble the car for free, but also produce an emotional response to the act of making it, on which Mercedes Benz as a company could reflect and report? Did the Mercedes Benz factory find itself in the maze of a Verwoerdian experiment? And if what we are doing here is observing and reflecting on that response, is this not also our wager?

Left with these questions, which we can only pose here, our overarching concern is what one does with an installation that holds and withholds within its body, if not a memory of tests with the capacity to hierarchize life, then at least questions of such tests. What is the proper home for such an uncanny test, if it can be called that? The actual Mandela car assembled by the workers has been housed in the Apartheid Museum to be remembered and, simultaneously, forgotten as a prop in reconciliatory nation building. But neither the museum nor the gallery seem as appropriate as the university, specifically the University of Fort Hare, as the site at which the body of Red will come to rest. Fort Hare is an institution at which tests have been resisted; indeed, at the same time as Verwoerd was conducting his experiments, D.D.T. Jabavu, writing from Fort Hare, states: 'We scarcely need to mention the general failure of intelligence tests that were in fashion a few years ago, seeking to discredit the mentality of aboriginal Africans'. 53 The point is not that we ought to reject the test, as Jabavu does, for in his own words Jabavu examines and then fails these tests. Which is to say, there is no walking out on this test one is always already taking. And like Verwoerd's research subject we cite in our epigraph, there was no failing Red's test that entrapped and shocked us at each turn. To fail, as we did several times and as we do here, again, is already to have passed into a space where one is presumed to be a fully human introspective subject. 54

The buried, the repressed, of the post-apartheid is apartheid's psychotechnical test, which continues to organize and orient the present, to 'partition' and to apportion life and 
death, to affirm, in the hollowed out space of introspective reflection, a notion of humanness the origins of which we cannot recall. There is, then, a question of inclusion and exclusion, but this question has on its horizon a memory of the mechanisms through which the human has been produced. Red intervenes by attempting to make that memory available in and as the staging of an uncanny double of the test, Red as an uncanny double of Verwoerd's test, particularly the experimental vocational test and all those vocational tests that operate outside of awareness in 'situations of every-day life'. This hypothesis, however, if we can call it that, will not yield to an empirical test; there is no paper trail that runs from Stellenbosch through the labor bureau system to East London. If the post-apartheid is in the aftershocks of Verwoerd's experiment, and if Red can be read as an uncanny double that brings this to light, it has to be approached symptomatically; Red as a symptom - in the strong sense of the term - of the repression of apartheid that began, it has been argued, almost the moment apartheid was named as such. 55

If Red was an uncanny test assembled and exhibited in a home, the Ann Bryant gallery, which is no longer a home, Freud does not hold the key to the problem. 56 In his essay on the uncanny, Freud is absolutely certain that fears of mechanical doubles are not essential to the experience of the uncanny; a car body mistaken for a corpse, a clock for an 'E', these can be uncanny, Freud argues, only insofar as they represent repressed wishes and surmounted beliefs, only insofar as they recall the 'primitive'. This is Freud at his most reductive, seeing in human-machine relationships only the confirmation of psychoanalytic concepts. It is, however, precisely by taking seriously the agency of the apparatus - as Benjamin did, tracing the changes in sense perception and memory made possible by the technological reproducibility of art - that we might be able to apprehend the ways in which apartheid lodged the technology of the test at the heart of the human and produced racialized inhumanity beyond the gates of the testable.

\section{Disclosure statement}

No potential conflict of interest was reported by the authors.

\section{Notes}

1 Research subject in H.F. Verwoerd, "A Method for the Experimental Production of Emotion," 358.

2 On background to Red and Red Assembly, see the editors' introduction to this issue.

3 Gush and Cairns, Red.

4 Mark Sanders, for example, argues that apartheid was, and remains, 'a proscription on mourning, specifically of the other', the corollary of which is that 'apartheid would be undone through condolence'. Sanders, "Remembering Apartheid." 60. See also Coetzee, "The Mind of Apartheid," 1-2.

5 Agamben, Stanzas, 20. 
6 Thembalethu Fikizolo evoked these associations when he stated that at the time of the strike there was 'blood, literally, on the shop floor'. Indeed, blood is invoked in the documentary at least twice more.

7 Freud, "The Uncanny," 637. Though there is a different sort of uncanny, too; it is not only the repressed returned, but also a set of beliefs 'surmounted' recurring, that which one does not believe any longer being confirmed. Freud, "The Uncanny," 639. Interestingly, the artist's trap is exactly what Freud is concerned with in his essay on the 'uncanny [das Unheimliche]', the way both lived experience and aesthetics induces a 'quality of feeling' the 'shade' of fright. Freud, "The Uncanny," 620, 641.

8 Dubow, Scientific Racism, 211.

9 Evan, Bureaucracy, 17.

10 Ibid., 102.

11 See Posel, The Making of Apartheid, 183-184.

12 Ibid., 184.

13 Völkerpsychologie is sometimes translated as ethno-psychology, though we leave it untranslated here.

14 Evans, Bureaucracy, 57.

15 Verwoerd, "The Distribution of 'attention," 495.

16 Ibid., 497-498.

17 Ibid., 497-498.

18 Ibid., 501.

19 Ibid., 505, n.

20 Verwoerd, "A method."

21 Ibid., 357.

22 Ibid., 358.

23 See Marx, "Hendrik Verwoerd," 91; Miller, "Science and Society," 638, 639-640, 650; Dubow, Scientific Racism, 218.

24 Verwoerd, "A method," 369.

25 Benjamin, Radio Benjamin, 367.

26 Ibid., 374. Benjamin's interest in experiments came largely from his engagement with Brecht's conception of experimental epic theatre.

27 Ibid., 374.

28 Benjamin, Illuminations, 228.

29 Ibid., 246, n.

30 Benjamin, The Work of Art, 30.

31 Ibid., 31.

32 Ibid., 31. 
33 Ibid., 31.

34 Benjamin, Illuminations, 228. Benjamin also shifts much of the discussion of 'tests' to the endnotes, probably at Adorno's insistence.

35 Ibid., 160.

36 Ibid., 160.

37 Ibid., 162.

38 Erfahrung is to be differentiated from Erlebnis, to merely live through something. As Hansen notes, etymologically rooted in fahren and Gefahr, journeying and danger respectively, Erfahrung 'stresses the subject's precarious mobility rather than a stable position of perception vis-a-vis an object'. Hansen, Cinema and Experience, loc 173.

39 Buck-Morss, "Aesthetics and Anaesthetics,"18.

40 Benjamin, Illuminations, 175.

41 Ibid., 235.

42 Ibid., 235.

43 Ibid., 255.

44 Freud, "Introductory lectures," 299.

45 Benjamin, Illuminations, 223.

46 After two minutes of Fikizolo talking, interrupted only by a stitched cut at fifty seconds, the camera goes to an image of the sea, and then, roughly every thirty seconds the shot changes to different images of harbor scenes, scenes outside the factory, at the loading docks, and back to the sea (to be precise, the average shot is twenty six seconds long, cutting twenty two times in ten minutes).

47 Benjamin, The Work of Art, 30.

48 Ibid., 30.

49 In the documentary, almost all employees interviewed discuss how quickly it was built without faults. Gush and Cairns, Red.

50 This was in fact how Verwoerd

entrapped his research subjects. A disc of a particular color would signal, ahead of time, that a reaction would soon be required. If the signal were a red disc with two dots and three lines, the trap would be red with three dots and two lines. Thus anxiety was induced through different shades of red.

51 Benjamin, The Work of Art, 30, emphasis added.

$5^{2}$ With the 'watchman' we are of course invoking Freud's spatial analogy for repression. Freud, "Introductory Lectures," 295-296.

53 Jabavu, "Higher education," 934-936.

54 Of course, Red Assembly-academics gathered on the top floor of the gallery, thinking about Red-confirmed that status, but also, in different ways, questioned it.

55 Verwoerd himself, in his 'attempts to whitewash the rhetoric of racism' for 'the world at large', displaced apartheid with 'separate development', racial difference with 
national difference. This would be followed by another repressive turn of the screw in official rhetoric under B.J. Vorster, 'plural democracy' displacing 'multi-nationalism', which by the 1980 os under P. W. Botha had been 'purged of open references to race'. McClintock and Nixon, "No Names Apart," 143.

56 The unheimlich, the unhomely, the unfamiliar, is precisely heimlich, homely, 'that class of the frightening which leads back to what is known of old and long familiar'. Freud, "The Uncanny," 620. We missed, on that first test at Red Assembly where we invoked the mother's body, the connection Freud makes between the uncanny and the mother's body, that "place where each one of us once lived once upon a time and in the beginning'. Freud, "Uncanny," 637. 


\section{Bibliography}

Agamben, Girogio. Stanzas: Word and Phantasm in Western Culture. Minneapolis: University of Minnesota, 1993.

Benjamin, Walter. The Work of Art in the Age of its Technological Reproducibility and Other Writings on Media. Edited by Michael Jennings and Thomas Levin. Cambridge, MA: Harvard University Press, 2008.

Benjamin, Walter. Illuminations: Walter Benjamin Essays and Reflections. Edited and translated by Hannah Arendt. New York: Schocken Books, 1969.

Benjamin, Walter. Radio Benjamin. Edited by Lecia Rosenthal. Translated by Jonathan Lutes with Lisa Harries Schumann and Diana K. Reese. London: Verso, 2014.

Buck-Morss, Susan. "Aesthetics and Anaesthetics: Walter Benjamin's Artwork Essay Reconsidered." October, 62 (1992): 3-41.

Cadava, Eduardo. "Words of Light: Theses on the Photography of History." Diacritics 2, 2-3 (1992): 84-114.

Coetzee, J. M. "The mind of apartheid: Geoffrey Cronjé (1907-)." Social Dynamics 17, 1 (1991): 1-35.

Dubow, Saul. Scientific Racism in Modern South Africa. Cambridge University Press, Cambridge, UK, 1995.

Evans, Ivan. Bureaucracy and Race: Native Administration in South Africa. Berkely, CA: University of California Press, 1997.

Freud, Sigmund. "The uncanny." New Literary History 7, 3 (1976): 619-648.

Freud, Sigmund. "Introductory lectures on psychoanalysis (part 3, 1916-1917)." In The Standard Edition of the Complete Psychological Works of Sigmund Freud. Edited and translated by James Strachey, 16. London: Hogarth Press, 1981.

Gush, Simon. Red. Anne Bryant Galley, 2015.

Gush, Simon, and Cairns, James. Red (documentary accompanying Red, the installation), 2014. http://www.simongush.net/red-2/

Hansen, Miriam Bratu. Cinema and Experience, Sigfried Kracauer, Walter Benjamin and Theador W. Adorno. Berkeley, CA.: University of California Press, Kindle Edition, 2012.

Jabavu, D.D.T. "Higher education and the professional training of the Bantu." South African Journal of Science 23 (1929): 934-936.

Marx, Christopher. "Hendrik Verwoerd and the Leipzig School of Psychology in 1926." Historia 58, 2 (2013): 91-118.

McClintock, Ann, and Rob Nixon. "No Names Apart: The Separation of Word and History in Derrida's 'Le Dernier Mot du Racisme'." Critical Inquiry 13 (1986): 140- 154.

Miller, Roberta Balstad. "Science and Society in the Early Career of H. F. Verwoerd." Journal of Southern African Studies, 19, 4 (1993): 634-661.

Posel, Deborah. The Making of Apartheid 1948-1961: Conflict and Compromise. Oxford Scholarship online, Oxford: Oxford University Press, 2011, originally published 1991.

Sanders, Mark. “Remembering Apartheid." Diacritics 32, 3-4 (2002): 60-80.

Verwoerd, Hendrik Frensch. "The distribution of 'attention' and its testing." Journal of Applied Psychology, 12, 5 (1928): 595-601. 
Verwoed, Hendrik Frensch. "A method for the experimental production of emotions." The American Journal of Psychology, 37, 3 (1926): 357-371. 